\title{
THE USE OF THERMOGRAPHIC CAMERA IN STROKE DIAGNOSTICS - INTRODUCTORY REPORT
}

\section{ZASTOSOWANIE KAMERY TERMOWIZYJNEJ W DIAGNOSTYCE UDARÓW MÓZGU - DONIESIENIE WSTĘPNE}

\author{
Jolanta Piskorz ${ }^{1(\mathrm{~A}, \mathrm{~B}, \mathrm{C}, \mathrm{D})}$, Gustaw Wójcik ${ }^{2,3(\mathrm{~A}, \mathrm{~B}, \mathrm{C}, \mathrm{D}) \text {, }}$ \\ Joanna Iłżecka ${ }^{4(\mathrm{C}, \mathrm{E}, \mathrm{F})}$, Włodzimierz Bulikowski ${ }^{2(\mathrm{C}, \mathrm{E}, \mathrm{F})}$
}

\author{
${ }^{1}$ Department of Anesthesiology and Intensive Care, \\ Zofia Tarnowska from the Zamoyskis Provincial Hospital in Tarnobrzeg, Poland \\ ${ }^{2}$ Department of Rehabilitation, Physiotherapy and Balneotherapy of Medical University in Lublin, Poland \\ ${ }^{3}$ Department of Imaging Diagnosis - Zofia Tarnowska from the Zamoyskis Provincial Hospital in Tarnobrzeg, Poland \\ ${ }^{4}$ Department of Rehabilitation, Physiotherapy and Balneotherapy, \\ Independent Laboratory of Neurological Rehabilitation of Medical University in Lublin, Poland
}

\author{
Authors' contribution \\ Wkład autorów: \\ A. Study design/planning \\ zaplanowanie badań \\ B. Data collection/entry \\ zebranie danych \\ C. Data analysis/statistics \\ dane - analiza i statystyki \\ D. Data interpretation \\ interpretacja danych \\ E. Preparation of manuscript \\ przygotowanie artykułu \\ F. Literature analysis/search \\ wyszukiwanie i analiza literatury \\ G. Funds collection \\ zebranie funduszy
}

\begin{abstract}
Summary
Background. Due to the serious course of most severe vascular injuries of the brain, there is a necessity to look for new diagnostic methods which are the least invasive for the patient. Objectives: the evaluation of the usefulness of thermographic camera in stroke diagnostics.

Material and methods. The research included 38 patients hospitalised due to cerebrovascular accident in the Intensive Therapy Ward and Neurology Ward. The patients were diagnosed according to EBM (evidence based medicine) by means of CT, then a series of images were taken by means of thermographic camera. The examinations were conducted on the first day of the stroke, preceded by head tomography, and next on the fourth day after the stroke.

Results. The examinations showed statistically significant $(\mathrm{p}<0.05)$ decrease in the temperature in the brain stroke area in relation to the healthy part both on the first and the fourth day. The difference in the average temperature changes between the cerebral infarction and intracerebral hemorrhage on the first and the fourth day was not statistically significant $(P>0.05)$. The difference in the average temperature changes in the brain stroke area (irrespective of its type) between the first and the fourth day was statistically significant $(p<0.05)$. The difference in the average temperature changes between the smaller and the bigger focal areas in CT on the first and the fourth day was not statistically significant $(P>0.05)$. No significant correlation was observed between the average temperature changes and the clinical state of patients evaluated according to ESS (Epworth Sleepiness Scale) during the first day (p.0.05).

Conclusion. Thermographic camera is a useful tool in brain stroke diagnostics, however it does not differentiate between hemorrhagic and ischemic strokes.
\end{abstract}

Keywords: stroke, cerebral infarction, thermal imaging camera, computer tomography

\section{Streszczenie}

Wstęp. W związku z ciężkim przebiegiem większości ostrych naczyniowych uszkodzeń mózgu istnieje konieczność poszukiwania nowych metod diagnostycznych jak najmniej inwazyjnych dla chorego. Cel pracy: ocena przydatności kamery termowizyjnej w diagnostyce udarów mózgu.

Materiał i metody. Badaniem objęto 38 pacjentów hospitalizowanych w Oddziale Intensywnej Terapii i Oddziale Neurologii z powodu udarów mózgu. Pacjentów diagnozowano zgodnie z zasadami EBM przy użyciu TK, a następnie wykonywano serię zdjęć przy pomocy kamery termowizyjnej FLIR E 30. Badania były wykonywane w I dobie udaru mózgu po diagnostyce tomograficznej głowy, a następnie w IV dobie po udarze.

Wyniki. Badania wykazały istotne statystycznie $(\mathrm{p}<0.05)$ obniżenie temperatury okolicy objętej udarem mózgu w odniesieniu do strony zdrowej zarówno w I jak i w IV dobie pomiaru. Różnica średnich zmian temperatur pomiędzy zawałem mózgu i krwotokiem śródmózgowym w I i IV dobie nie była istotna statystycznie (P>0.05). Różnica średnich zmian temperatur okolic objętych udarem (niezależnie od jego rodzaju) pomiędzy I i IV dobą badania była istotna statystycznie $(\mathrm{p}<0.05)$. Różnica średnich zmian temperatur pomiędzy mniejszym i większym ogniskiem w TK w I i IV dobie nie była istotna statystycznie $(P>0.05)$. Nie obserwowano istotnej korelacji średnich zmian temperatur ze stanem klinicznym chorych ocenianych według skali ESS w I dobie ( $p>0.05)$. Wnioski. Kamera termowizyjna jest przydatnym narzędziem w diagnostyce udarów mózgu, jednak nie różnicuje udarów na krwotoczne i niedokrwienne.

Słowa kluczowe: udar mózgu, kamera termowizyjna, tomografia komputerowa, rezonans magnetyczny
Tables: 5

Figures: 0

References: 21

Submitted: 31.03 .2015

Accepted: 15.10 .2015

Piskorz J, Wojcik G, Ilzecka J, Bulikowski W. The use of thermographic camera in stroke diagnostics - introductory report. Health Problems of Civilization 2016; 1(10): 14-19. DOI: 10.5114/hpc.2016.58203

Address for correspondence / Adres korespondencyjny: Gustaw Wójcik, Department of Rehabilitation, Physiotherapy and Balneoterapy, Medical University of Lublin, 6 Chodźki Str, 20-093 Lublin, Poland, e-mail: gustaww@tlen.pl, phone: +48 814486783

Copyright: ( 2016 Pope John Paul II State School of Higher Education in Biała Podlaska. This is an Open Access journal, all articles are distributed under the terms of the Creative Commons Attribution-NonCommercial-ShareAlike 4.0 International (CC BY-NC-SA 4.0) License (http://creativecommons.org/licenses/by-nc-sa/4.0/), allowing third parties to copy and redistribute the material in any medium or format and to remix, transform, and build upon the material, provided the original work is properly cited and states its license. 


\section{Introduction}

Stroke in one of the main reasons of morbidness and mortality in the world [1]. Every year about $4.5 \mathrm{ml}$ people in the world die of cerebrovascular accident, of whom $2 / 3$ in non-industralised countries [2]. In Europe, every year about $1 \mathrm{ml}$ people show the symptoms of stroke, of which $1 / 3$ die, while in $1 / 3$ there remains a disability of various degree [3]. Whereas in Poland, on the basis of epidemiological research conducted at the beginning of the 1990s, it was found that every year the symptoms of stroke occur in about 60 thousand people, half of whom die during the year, while the half who survive demonstrate permanent disability $[3,4]$.

Ischemic strokes (cerebral infarctions) account for $80-85 \%$ of all strokes, the remaining 15-20\% are hemorrhagic strokes [5]. The clinical picture differs depending on the location of the stroke and its size. The most frequent reason of ischemic strokes is thrombosis appearing locally or in consequence of an arterial embolism or heart embolism. Ischemic stroke may also be caused chemodynamically [6]. Intracerebral hemorrhage is a result of vessel damage, its rupture and bleeding into the brain tissue. It can appear due to hypertension, injury, coagulability disorder, venous malformation, amyloid angiopathy, cocaine or amphetamine abuse. Brain function becomes disturbed when the blood flow in the brain decreases below $50 \mathrm{ml} / 100 \mathrm{~g} / \mathrm{min}$. Irreversible damage happens when this flow is lower than $30 \mathrm{ml} / 100 \mathrm{~g} / \mathrm{min}$. When the blood flow through the brain tissue is blocked, the metabolism of this organ becomes disturbed already after 30 seconds. After $1 \mathrm{~min}$. the function of neurons may cease. After a 5-minute blockage in the blood flow anoxy starts a chain reaction which may finally lead to cerebral infarction of the brain [7].

Stroke recognition is based on head CT. CT is a method allowing us to diagnose a hemorrhage and determine its location because, in CT, freshly extravasated blood has significantly higher density than the tissue surrounding it. In case of ischemic stroke more precise seems the examination by means of echo polar imaging technique of diffusion MRI, since early ischemic changes appear with the increased water content; then, the stroke focal area becomes well isolated in Fluid Light Attenuation Inversion Recovery (FLAIR) and in T2-weighted images [7]. Diffusion MRI is a more reliable method of early brain ischemia detection. This examination allows us to distinguish severe ischemic stroke from other pathological processes. Moreover, it provides additional information on the brain tissue micro-structure [8].

Visual thermography is totally non-invasive method of imaging. It consists of the evaluation of the intensity of infrared radiation in an examined body area and indicating the distribution of temperatures on its surface. In medicine thermograpgy is used to assess heat variations in living organisms during physiological life processes and in pathological states. Because the energy of heat radiation of tissues results from the disorder in blood circulation, it carries a lot of information which can contribute to achieving better therapeutic results. Slight variations in tissue heat may precede the appearance of clinical symptoms and may signal pathologies in various organs and systems. Most pathological states are accompanied by local disturbances in blood circulation in the affected area and changes in the cell metabolism $[9,10,11]$.

\section{Objectives}

The aim of the work is to evaluate the usefulness of thermographic camera in the diagnostics of hemorrhagic and ischemic strokes, using the temperature difference between the healthy brain tissue area and the damageaffected area.

\section{Material and methods}

The research included 38 patients ( 9 women and 29 men) hospitalised due to cerebrovascular accident in the Intensive Therapy Ward and Neurology Ward in Tarnobrzeg. Of all the patients included in the study, 28 patients were diagnosed with ischemic stroke (cerebral infarction) while 10 patients with intracerebral hemorrhage. The age of patients ranged from 51 to 78, the average age was 66.5. The patients were diagnosed according to EBM by means of CT, then a series of images were taken by means of the thermographic camera FLIR E 30.

Following their admission to the wards the patients were also examined by a neurologist using the ESS (European Stroke Scale). According to the above scale, the patients were assessed as 0-70 points.

The patients were divided into 2 groups: those whose CT showed a smaller stroke area - up to $5 \mathrm{~cm}$ (16 patients) and those with the stroke area larger than $5 \mathrm{~cm}$ (22 patients).

Heat was measured by means of thermographic camera in two places: the right temporal area and the left temporal area from the distance of $30 \mathrm{~cm}$. The selected distance was optimal and, simultaneously, minimal to register precise temperatures of the selected surface. These examinations followed the CT diagnostics of the head on the first day of the stroke, and then on the fourth day of the stroke. An hour before the thermographic test the 
patients were put in a lying position so that the areas examined did not touch the bedding, and two hours before the examination the head was not physically cooled. These actions were performed in order to achieve reliable temperature measurements.

The results of the examinations were presented as average and standard deviations. The results were developed statistically using the t-Student test for independent variables. The correlation was calculated using the Pearson's test. $\mathrm{P}<0.05$ was assumed as the level of statistical significance.

The research received a positive recommendation of the Board of Bioethics of Medical University in Lublin (KE-0254/84/2013)

\section{Results}

The research showed statistically significant $(\mathrm{p}<0.005)$ temperature decrease in the stroke area in relation to the healthy area both on the first and the fourth day.

Table 1. Average temperatures of the healthy area and the stroke area and the statistical significance of temperature difference on the first and the fourth day since the onset of the illness

\begin{tabular}{|c|c|c|c|}
\hline Day & $\begin{array}{r}\text { Temperature }\left({ }^{\circ} \mathbf{C}\right) \\
\text { Healthy hemisphere }\end{array}$ & $\begin{array}{c}\text { Temperature }\left({ }^{\circ} \mathbf{C}\right) \\
\text { Stroke hemisphere }\end{array}$ & Statistical significance (p) \\
\hline I & $35.55 \pm 0.76$ & $35.06 \pm 0.77$ & $\mathrm{P}=0.007^{*}$ \\
\hline IV & $35.58 \pm 0.75$ & $35.20 \pm 0.77$ & $\mathrm{P}=0.03^{*}$ \\
\hline
\end{tabular}

* Statistical significance

Source: own elaboration

The difference in average temperature changes between cerebral infarction and intracerebral hemorrhage on the first and fourth day was not statistically significant $(\mathrm{P}>0.05)$. The data was presented in Table 2.

Table 2. Average temperature changes between cerebral infarction and intracerebral hemorrhage on the first and the fourth day

\begin{tabular}{|c|c|c|c|}
\hline Day & $\begin{array}{c}\text { Average temperature change }\left({ }^{\circ} \mathbf{C}\right) \\
\text { Cerebral infarction }\end{array}$ & $\begin{array}{c}\text { Average temperature change }\left({ }^{\circ} \mathbf{C}\right) \\
\text { Intracerebral hemorrhage }\end{array}$ & Statistical significance (p) \\
\hline I & $0.46 \pm 0.17$ & $0.54 \pm 0.25$ & $\mathrm{P}=0.33$ \\
\hline IV & $0.37 \pm 0.15$ & $0.42 \pm 0.16$ & $\mathrm{P}=0.41$ \\
\hline
\end{tabular}

Source: own elaboration

The difference in average temperature changes in the stroke area (irrespective of its type) between the first and the fourth day of examination was statistically significant $(0.48 \pm 0.19,0.38 \pm 0.16, p=0.01)$. Significantly lower average temperature change was observed on the fourth day of the stroke.

The difference in the average temperature changes in cerebral infarction between the first and the fourth day was statistically significant $(\mathrm{p}<0.05)$, however the difference in the average temperature changes in the intracerebral hemorrhage between the first and the fourth day was statistically insignificant $(p>0.05)$. The data was presented in Table 3.

Table 3. Difference in average temperature changes between cerebral infarction and intracerebral hemorrhage between the first and the fourth day

\begin{tabular}{|c|c|c|c|}
\hline Type of stroke & $\begin{array}{c}\text { Average temperature change }\left({ }^{\circ} \mathbf{C}\right) \\
\text { Day I }\end{array}$ & $\begin{array}{c}\text { Average temperature change }\left({ }^{\circ} \mathbf{C}\right) \\
\text { Day IV }\end{array}$ & Statistical significance (p) \\
\hline $\begin{array}{c}\text { Cerebral } \\
\text { infarction }\end{array}$ & $0.46 \pm 0.17$ & $0.37 \pm 0.15$ & $\mathrm{P}=0.03^{*}$ \\
\hline $\begin{array}{c}\text { Intracerebral } \\
\text { hemorrhage }\end{array}$ & $0.54 \pm 0.25$ & $0.42 \pm 0.16$ & $\mathrm{P}=0.23$ \\
\hline
\end{tabular}

*Statistical significance

Source: own elaboration

The difference in average temperature changes between the smaller and the bigger focal area in CT on the first and the fourth day was not statistically significant $(\mathrm{P}>0.05)$. The data was presented in Table 4 . 
Table 4. Difference in average temperature changes between the smaller and the bigger focal area in CT on the first and the fourth day

\begin{tabular}{|c|c|c|c|}
\hline Day & $\begin{array}{c}\text { Average temperature change }\left({ }^{\circ} \mathbf{C}\right) \\
\text { Smaller focal area } \\
(<\mathbf{5} \mathbf{~ c m})\end{array}$ & $\begin{array}{c}\text { Average temperature change }\left({ }^{\circ} \mathbf{C}\right) \\
\text { Bigger focal area } \\
(>\mathbf{5} \mathbf{~ c m})\end{array}$ & Statistical significance (p) \\
\hline I & $0.41 \pm 0.09$ & $0.53 \pm 0.24$ & $\mathrm{P}=0.07$ \\
\hline IV & $0.34 \pm 0.12$ & $0.41 \pm 0.17$ & $\mathrm{P}=0.15$ \\
\hline
\end{tabular}

Source: own elaboration

The difference in average temperature changes of the smaller focal area in CT between the first and the fourth day was statistically significant $(\mathrm{p}<0.05)$, however the difference in average temperature changes of the bigger focal area in CT between the first and the fourth day was statistically insignificant $(p>0.05)$. The data was presented in Table 5.

Table 5. Difference in average temperature changes of the smaller focal area and the bigger focal area in CT between the first day and the fourth day

\begin{tabular}{|c|c|c|c|}
\hline $\begin{array}{c}\text { Type of } \\
\text { focal area }\end{array}$ & $\begin{array}{c}\text { Average temperature change }\left({ }^{\circ} \mathbf{C}\right) \\
\text { Day I }\end{array}$ & $\begin{array}{c}\text { Average temperature change }\left({ }^{\circ} \mathbf{C}\right) \\
\text { Day IV }\end{array}$ & Statistical significance (p) \\
\hline $\begin{array}{c}\text { Smaller focal } \\
\text { area }(<5 \mathrm{~cm})\end{array}$ & $0.41 \pm 0.09$ & $0.34 \pm 0.12$ & $\mathrm{P}=0.04^{*}$ \\
\hline $\begin{array}{c}\text { Bigger focal } \\
\text { area }(>5 \mathrm{~cm})\end{array}$ & $0.53 \pm 0.24$ & $0.41 \pm 0.17$ & $\mathrm{P}=0.06$ \\
\hline
\end{tabular}

*Statistical significance

Source: own elaboration

No significant correlation was observed between the average temperature changes and the clinical state of patients in accordance with ESS on the first day $(p=0.53)$.

\section{Discussion}

The temperature variations between the healthy and the damaged brain areas were analysed in the course of examinations conducted with the use of thermographic camera. These changes were due to disorders in blood perfusion, as a result of which a chain reaction started on the level of neurons, leading to cell function disturbance and, consequently, their death. The examinations showed statistically significant decrease in the temperature in the stroke affected area (irrespective of its type) in relation to the healthy part, both on the first and the fourth day of measurement. Unfortunately, this method appeared non-specific for strokes, since it does not allow us to differentiate between ischemic strokes and hemorrhagic strokes. It can be used for screening evaluation of disturbances in brain perfusion. The difference in average temperature changes in stroke areas (irrespective of its type) between the first and the fourth day of examination was statistically significant. This difference was significantly smaller on the fourth day. Probably on the fourth day of the stroke onset there appear some initial changes connected with the reorganization of the near-stroke zone, as a result of which there appears an almost $30 \%$ increase in the heat lost earlier due to brain perfusion disturbances in relation to the first day of stroke onset. The evolution of these changes refers both to disturbances connected with the damage caused by the lack of flow in brain vessels and to the damage connected with vessel rupture and intracerebral hemorrhage [12].

Clinical symptoms are not hemorrhagic stroke specific or ischemic stroke specific, therefore, the imaging examination is necessary in case of each individual patient. High attenuation blood image make possible to clinically differentiate between hemorrhage and cerebral infarction and, therefore, CT is generally used as an initial imaging examination in the ad hoc evaluation of the patient with brain stroke, particularly, if thrombolitic treatment is planned [13]. Kidwell et al. [14] prove in their research that MR can also successfully exclude the presence of acute hemorrhage, and certain sequences, e.g. DWI, are sensitive in imaging the earliest ischemic changes. However, Han et al. [15] report that the DWI sequence in diffusion MRI is often unreliable and the frequency range of false negative diffusion is from $3.5 \%$ to $25 \%$. Because of the easier access to CT in most emergency wards, this examination still continues to be the method selected in the initial evaluation of the patient, whereas the MR examination, performed later, may provide additional information. Thanks to MR, it is possible to discover small, permanent changes which would not be noticed earlier. In clinical practice, it is also of significant importance to differentiate between the stroke and a temporary ischemic attack (TIA). Traditional definition of TIA as a focal 
deficit lasting up to 24 hours assumes a much longer time period than it is necessary in the MRI to appear as a stroke. It was reported that $50 \%$ of patients demonstrating a less than 24-hour neurological deficit show the symptoms of ischemia in diffusion MRI, while 50\% of these patients show the symptoms of fixed infarction in the next T2-weighted images [16]. Johnston et al. [17] state that the risk of stroke and other vascular incidents is higher after the appearance of TIA than after the stroke (CVA). It contradicts the validity of the slower approach to diagnostics and treatment of patients with TIA. The risk of stroke following TIA after 90 days is about $10 \%$, half of which happens on the first two days. $25 \%$ of patients with TIA have a stroke or other vascular incidents within the next three months. Allmendinger et al [18] describe in their work the benefits of perfusion CT as the most frequently used diagnostic tool in acute ischemic stroke evaluation. It can be performed quickly and is generally accessible. Kontas et al. [19] list the benefits of perfusion CT as the most advanced method providing important information on chemodynamics of capillaries in brain parenchyma. However, they highlight the X-ray radiation doses which the patient receives during the examination. Amar [20] also points out to the early use of CT and MR in brain perfusion evaluation and determination of the ischemic focal area. Proper, fast and correct diagnostics allows selecting patients to thrombolitic treatment. Merino and Warach [21] emphasise that diffusion MRI is more precise than CT in detecting ischemic strokes. MR defines a wider range of acute and chronic vascular brain disorders than CT. Moreover, it is more sensitive in detecting acute ischemic incidents of the brain and, consequently, it can assist in taking decision on initiating correct treatment.

Using thermographic camera in early detection of brain flow pathologies may be beneficial for patients with less specific symptoms of brain strokes, yet, it does not prove itself as a diagnostic tool in differentiating between them. Therefore, it is necessary to conduct imaging examinations, such as CT, in order to determine precisely the brain pathology, even though this technique is connected with harmful effects of radiation on living organisms. Perfusion examinations carry even greater risk for the patient since they are connected with increased radiation dose and an additional intravenous injection of the contrast agent. Theromgraphic camera is a measuring tool which does not emit any radiation, therefore it does not pose a threat to human life. Conducting examinations using the infrared radiation is totally harmless for patients however, unfortunately, this method is characterised by very low sensitivity. Hopefully, the advance of technology will increase the sensitivity of detectors in thermographic cameras, which will improve their diagnostic possibilities.

\section{Conclusions}

1. Thermographic camera is a useful and safe tool in brain stroke diagnosis. However, this method does not offer a possibility to differentiate between hemorrhagic and ischemic strokes, which is its defect.

2. Temperature change in the stroke area does not depend on the size of the focal area in CT.

3. Temperature change in the stroke area does not correlate with the clinical state of patients.

\section{References:}

1. Diener HC, Hennerici M, Ferro J, Sivenius J. et al. European Stroke Initiative Recommendations for Stroke Management - Update, Cerebrovasc. Dis.,2003; 16: 311-337.

2. Wolfe CD. The impact of stroke. Brithis Med. Bulletin. 2000; 56: 275-286.

3. Szczudlik A, Gryz E, Szermer P. Udar mózgu. Kraków: Uniwersytet Jagielloński; 2007 (in Polish).

4. Członkowska A, Ryglewicz D, Weissbein T, Barańska-Gieruszczak M., et al. A prospective community - based study of stroke in Warsaw, Poland. Stroke. 1994; 25: 547-551.

5. Kollef MH, Bedient TJ, Isakow W, Witt CA. Kompendium intensywnej terapii. Copyright by MediPage, Warszawa. 2010; 50: 428-430 (in Polish).

6. Wolff HP., Weihrauch TR., Kokot F. Terapia internistyczna. Urban Partner, Wrocław. 2003; 16: 137-138 (in Polish).

7. Rowland LP., Pedley TA. Merritt's Neurology. Elsevier U\&P, NY. 2010; 1: 276-278.

8. Fung SH. et al. MR diffusion imaging in ischemic stroke. Neuroimaging Clinics of North America. 2011; 21(2): 345-77.

9. Knobel RB, Guenther BD, Rice HE. Thermoregulation and thermography in neonatal physiology and disease. Biol Res Nurs. 2011; 13(3): 274-82.

10. Gorbach AM, Heiss JD, Kopylew L. Oldfield EH. Intraoperative infrared imaging of brain tumors. J Neurosurg. 2004; 101(6): 960-9.

11. Mikulska D. Contemporary applications of infrared imaging in medical diagnostics. Annales Academiae Medicae Stetinensis. 2006; 52(1): 35-9. 
12. Fisher M, Ginsberg M. Current Concepts of the Ischemic Penumbra. Stroke. 2004; 35: 2657-8.

13. Kasdon DL. Cerebellar hemorrhage with decreased absorption values on computed tomography: a case report. Neuroradiology. 1997; 13: 265-266.

14. Kidwell CS, Alger JR, Di Salle F, Starkman S. et al. Diffusion MRI in patients with transient ischemic attacks. Stroke. 1999; 30: 1174-1180.

15. Han SJ, Harris AD, Coutts SB, Frayne R. Acute ischemic stroke lasting for 5 days without definite lesions on diffusion-weighted magnetic resonance imaging in a patient with severe leukoaraiosis. J Stroke Cerebrovasc Dis. 2011; 20(5): 482-4.

16. Albers GW, Caplan LR, Easton JD, Fayad BP, et al. Transient ischemic attack - proposal for a new definition. N. Engl J Med. 2002; 347: 1713-1716.

17. Johnston SC., Royhwell PM., Nguyen - Huynh MN., Gilen MF. et al.: Validation and refinement of scores to predict very early stroke risk after transient ischemic attack. Lancet. 2007; 36(8): 283-292.

18. Allmendinger AM, Tang ER, Lui YW, Spector V, et al. Imaging of stroke: Part 1, Perfusion CT - overviev of imaging technique, interpretation pearls and common pitfalls. American Journal of Roentgenology. 2012; 198(1): 52-62.

19. Kontas AA, Goldmarkher GV, Lee TY., et al. CT perfusion imaging in acute stroke. Neuroimaging Clinics of North America. 2011; 21(2): 215-38.

20. Amar AP. Brain and vascular imaging of acute stroke. Word Neurosurgery. 2011; 76(6): 53-8.

21. Merino JG., Warach S. Imaging of acute stroke. Nature Reviews Neurology. 2010; 6(10): 560-71. 